\title{
МОВОЗНАВСТВО, ЛІТЕРАТУРОЗНАВСТВО
}

\section{УДК УДК 82-31.09}

Антоніна АНІСТРАНЕНКО,

ВДНЗ України "Буковинський державний медичний університет",

Чернівці (Україна)

\section{Antonina ANISTRATENKO,}

Higher State Educational Establishment of Ukraine «Bukovinian State Medical University» Chernivtsi (Ukraine)

oirak@bsmu.edu.ua

\author{
СУЧАСНИЙ СТАН РОЗРОБЛЕННЯ І \\ ВИВЧЕННЯ АЛЬТЕРНАТИВНОЇ \\ ICTOРІЇ ЯК МЕТАЖАНРУ
}

CURRENT STATUS, DEVELOPMENT

AND RESERCH OF ALTERNATIVE

HISTORY AS METAGENRE
Ключевые слова: альтернативной истории, особенности жанра, генезис жанра, фантастика, исторический роман, подражание, роман.
Анистратенко Антонина. Современное состояние разработки и изучения альтернативной истории как метажанра

Специальные символы альтернативной истории как жанра объединены в современной постмодернистской прозе и используют последнего как форму для нового смысла. Это относится к подходу к литературе, когда она рассматривается в виде документа, реального факта для создания дополнительного доверия путем прямого подражания языковому и культурному коду журналистики. Критика общества также является наиболее значимым мотивом творчества в различных альтернативноисторических произведениях, формальным и семантическим фоном схем в фантастических романах.
Альтернативна історія (AI) - історикокультурний напрям студій 3 історіографії, культурології, генології, феноменології, які за основу дослідження приймають багато вимірність історичного часу. В дискурсі літератури термін має вужче значення метажанру. „Остаточно закріпилась AI у світовому письменстві в епоху модернізму. Як жанр художньої літератури вона бере початок у творчості видатного американського письменника М. Твена". Найвідоміші твори в цьому жанрі - ,3000 років серед мікробів” М. Твена (1905), „І прогримів грім” Р. Бредбері (1952), „Еутопія” П. Андерсона (1967), „Хай живе Трансатлантичний тунель! Ура!” Г. Гаррісона (1972), „Експеримент доктора Гайдеггера” Н. Готорна (1837), „Хай не зійде темрява” Л. С. де Кампа (1939), „Острів Крим” В. Аксьонова (1979), „Спадкоємець” К. Буличова (1992), „Фатерланд” Р. Харриса (1992), „Інше небо” А. Лазарчука (1993), „Втрачені сторінки” П. Ді
Філіппо (1998), „72 літери” Т. Чан (2000), „Варіант „Біс ” С. Анісімова (2004).

Найвідоміші дослідники творів жанру альтернативна історія: С. Бєрєжной (Росія), Г. Вайт (США), Дж. Клют (США), Р. Коулі (США), В. Лещенко (Росія), А Ройфе (Росія), С. Соболєв (Україна), Н. Чорна (Росія).

Роман М. Твена „Янкі з Коннектикута при дворі короля Артура" (1889) написаний на матеріалі реальних історичних нотаток, хронік, свідчень, проте сюжетним каталізатором $\epsilon$ введений письменником фантастичний елемент, який можна узагальнено назвати: „що було б, якби...”. Точка дивергенції, за яку править введений ззовні поворотний елемент, який змінює звичний (відомий, реальний) перебіг історії - це найважливіший жанровий маркер, який допомагає ідентифікувати твір як такий, що написаний у жанрі альтернативної історії.

Зміна історії в минулому (навіть якщо йде- 
ться про майбутнє суспільства) створює лакуну для розгортання сюжетних схем фантастичного виду літератури, тобто готує вдячний грунт для реалізації типових фабульних конструкцій наукової фантастики та фентезі, наприклад, подорожі в часі, втручання інопланетних цивілізацій чи окремих представників позаземних форм життя, результати й зміни перебігу НТР тощо.

Жанровими маркерами творів AI, окрім умови альтернативності, також вважаємо балансування на межі глобального та часткового, тобто history i story; у творах AI розглядають можливі історії розвитку, сценарії життя винятково людської цивілізації, у стосунку до офіційної історіографії, ,а не розумних динозаврів, ходячих дерев чи мишей"1, як на те вказує Гоксер (псевдонім засновника сайту http://militera.lib.ru, організатора конкурсу письменників-альтернативістів).

Найважливішими стильовими маркерами AI, 3 досвіду відомих на сьогодні художніх текстів, виступають такі: занурення в національно-ментальні особливості історичного розвитку та закони перебігу й зміни історичних подій; герменевтичний зв'язок AI 3 християнством (переважна кількість творів AI, написані на матеріалі історії людства після появи християнства, або, власне, на матеріалі цього процесу чи його заперечення); занурення в міфологію та езотеричні знання; критика теорії лінійного хронотопу в загальному сенсі; залучення міметичних методів інших видів мистецтва, науки та широкий спектр формально-видових утворень.

До типових жанрових маркерів належать такі: зміна історії в минулому (,що було б, якби...”), епічність та епохальність оповіді, тобто опис життя бодай цілого покоління у зміненій історичній реальності, національна прив'язаність персонажів, алюзій, логічних ланцюжків i, разом 3 тим, притчева узагальненість фабули.

За Гоксером, жанр альтернативної історії має три принципових положення, 3 яких випливають його ознаки:

- до точки дивергенції описана історія (history) повністю відповідає зафіксованій світовій чи національній історії, інакше кажучи, альтернативна історія не може базуватися на криптоісторії, гіпотезах, вигадках, в творі повинні фігурувати й діяти реальні історичні постаті;

- альтернативна історія - це історія людства, тому в творі цього жанру дійовими персонажами не можуть виступати анімалістичні образи чи представники позаземних ци- вілізацій;

- якщо у творі використовується художній прийом 3 паралельним світом, віртуальною реальністю, то цей світ повинен бути ідентичним до реального, цивілізаційного простору до точки дивергенції та істотно відрізнятися після неї.

Зі статуту конкурсу сучасних письменників, що працюють у жанрі альтернативної історії, можна виокремити тези для створення дефініції цього жанру, як його бачать літературознавці та критики у слов'янському просторі. За участю М. Мошкова та письменників т. зв. „харківської школи фентезі” було організовано конкурс серед письменників-альтернативістів. Він проводився уже вшосте, отже, за цей час журі та зацікавлені читачі створили літературознавчі, естетичні та навіть філософські критерії жанру, що формується у метажанр тепер вже й на грунті слов'янських літератур.

Виникнення жанру AI на межі фантастики й історичного роману підтверджується спільним функціонуванням у ньому маркерів обох похідних жанрів. Читаємо у енциклопедичній статті Дж. Клюта: „Альтернативна історія - це не комп'ютерна гра-стратегія, яку можна „зберегти”, „переграти” і потім знову „перезберегти", і не світські бесіди про те, що „могло би бути, якби..."2. Альтернативна історія „дозволяє проаналізувати хід історичних подій, оцінити роль в історії тих чи тих постатей i випадкових факторів, i, разом 3 тим, - що найголовніше - зрозуміти закономірності історичних подій, щоб у реальності уникнути повторення колись зроблених помилок"3.

Амбівалентність ознак цього жанру пов'язана 3 тим, що він виокремився 3 царини наукової фантастики та виробився на жанровій матриці історичного роману.

Жанрова схема історичного роману успішно працює для творів альтернативної історії. Адже сама альтернативність виникла у полі icmoризму, що прийшов на зміну історіі. Поява історичного роману пов'язана 3 відродженням історичної прози в епоху Середньовіччя, модифікацією романної оповідної структури, й перетворенням історичної літератури в епоху Нового часу 3 міфологічно-притчевого - в епічний рід, пізніше канонізований, жанр роману. „Історична проза - своєрідний жанр, в якому сполучаються фактографічність, науковість позиції й стиль викладу, що базується на засадах поетики", Ц. Це визначення С. Абрамовича стосується генези історичної прози. Але у XX ст. ,[...] у зв'язку зі становленням тоталітарних режимів у Європі й практикою „,перепи- 
сування" історії [...] численні виклади історичних подій[...] все більше тяжіють до міфологізації [...] та спостерігаються численні стилізації5.

Прямування до узагальнення наділило історію роллю посередника між філософією i релігією: вона перетворилась на світську релігію. Тож ії стосунки 3 церквою набули двозначності. Вона заступала „божественне Провидіння" умінням пояснювати хід речей, але водночас історія залишалась поєднаною 3 Богом (unmittelbar zu Gott), в ній завжди залишалось щось неприступне для раціональної історичної реконструкції. Свого часу Гумбольдт порівняв історію $з$ мистецтвом, що „також $є$ не стільки наслідуванням образу, скільки вживанням в Ідею, що гніздиться в цьому образі” (,,[... auch nicht sowohl Nachahmung derGestalt, als Versinnlichung der inder Gestaltruhenden Ideeist" a 6 [423].

Так філософія історії повернулась до полеміки між історією та романом. Д. Дідро, говорячи про С. Річардсона, протиставляв історію як „поганий роман”- романові як „добрій історіі”. Саме роман, на думку О. Тьєрі, висуваючи ясні й послідовні засади розуміння, наближається до істини більшою мірою, ніж укрита пилом історія, здатна лише нагромаджувати факти без їх внутрішнього логічного зв'язку. Довга й заплутана історія побутування історичного роману, зокрема в англійській (В. Скотт) та французькій літературах (Ж. Мішле), трохи розборонила ворогуючі табори „фантазерів” та „істориків”.

В історичній науці та художній літературі все частіше реалізується прагнення людини змінити щось в історії, щоб повернути іiі в „правильне” русло. Заміна фактів чи їх трактування лише політизуе історичні хроніки та саму історіографію, але бажаного виправлення „,історичної сучасності” не дає. Розуміючи логіку подій, особливо на певній хронотопній відстані, успішно можна створювати проекти нових варіантів, накладаючи їх на вже відомі схеми історичних подій минулих епох. Особливо вдало за допомогою цього методу можна реконструювати національну історію. Тож перша несмілива спроба відбулась 1889 року.

А в XX ст. у есеїстиці, драмі, малій прозі, а пізніше й у романі з'являються елементи AI. Історичні проміжки та моменти, що найбільше зацікавили зарубіжних письменників, переважно належать до історії воєн та зламів століття, а також стосуються історії християнства. Нато-

\footnotetext{
а Не як імітація форми, а як образ, що спочиває в ідеї (перекл. авт.)
}

мість українські спроби переважно стосуються вітчизняної історії (часто - політичної) і належать до кінця XX - початку XXI ст. Це „РівнеРовно” О. Ірванця, „Долина Бельведеру” Я. Яновського, „Час смертохристів” Ю. Щербака, „VitaNostra” M. i C. Дяченків i, звичайно, „дефілядна" серія з трьох романів В. Кожелянка.

Величезна кількість (понад 1000 одиниць поданих творів на конкурс письменників-альтернативістів на сайті Гоксера!) творів фентезі та фантастики, що значаться під грифом AI, використовуючи його як бренд для успішного поширення книжкового продукту, оскільки в Європі нині цей жанр користується попитом читачів та увагою літературних критиків. Однак не завжди марковані такою абревіатурою тексти виходять за рамки масової літератури, особливо на грунті літпроцесу слов'янських держав. У російській літературі нині спостерігаємо інтенсивне наповнення корпусу текстів, позначених деякими маркерами цього жанру. Вони здобувають на кількості й часто втрачають на якості письменницького продукту.

Ось що пише про рідну йому літературу засновник найбільших інтернет-ресурсів 3 питання альтернативної історії А. Андрєєв у „Time o'clock: news-дневник фут-уролога”: „В основі моєї давньої бестіалогії лежить ідея про те, що в російській фантастиці давно закорінилась „фейлетонна епоха”. Оригінальних письменників 3 цілісним творчим методом немає вже років двадцять. Все, що є, - це гібриди-мутанти, склеєні 3 пістрявих огризків минулого" ". Не зупиняючись на тому, що його „давня бестіалогія” перебрана у Франца Бляя із книги „Бестіарій сучасної літератури”, , бачимо, що самобутніми й цілісними письменниками пан А. Андрєєв вважає братів А. та Б. Стругацьких та К. Буличова.

Підтримую естетичну концепцію російського інтернет-діяча; заперечуємо тільки зарахування харків'ян, М. та С. Дяченків, до російських письменників. Вони пишуть російською і українською мовами, або ж здійнюють авторизований переклад своїх творів українською.

У „своїй бестіарній” класифікації А. Андрєєв поділяє письменників-альтернативістів на „...,голівудських лепетальників”, що творяться гібридизацією Стругацьких та Голівуду, i на „крокодильників”, яких можна отримати, схрестивши письменників та філософів 3 радянським гумористичним журналом „Крокодил”. „[...] вони жартують досить подібно, навіть у тому випадку, коли пишуть про різне. Кастанеда плюс „Крокодил” дорівнює Пєлєвін, 
Толкієн плюс „Крокодил” дорівнює Пєрумов, російські народні казки плюс „Крокодил” дорівнює Успенський. В ту ж клітку втрапляє й рідкісне звірятко [...] Сорокін, цей вічний шестикласник, що розмальовує портрети у підручнику з літератури"9. В нашому дослідженні (див. п. 1.3., 1.4.) ми повернемося до згаданих письменників, щоправда, не в такому гротескному контексті, а в дискурсі стильових маркерів AI.

Наразі, звернімо увагу на другий важливий теоретичний елемент, - фантастичний і його роль в АI як жанрово-стильового компонента метажанру, що формується в українській літературі як жанрово-стильовий різновид альтернативна історія України.

Фантастика як метажанр у своєму апофеозі творить сагу-містифікацію на фантастичному грунті. Інакше кажучи, фантастична повість чи роман розробляє „світ” і надалі описує часовий проміжок життя персонажів у ньому (покоління). Так, імітуючи основні причинно-наслідкові схеми справжнього світу, фантастична література неминуче приходить до реалізації ,історіï" (чи історіографіï, або хоча би story). Для більш філігранного ефекту мімезису бажано, щоб „нова історія” (в ширшому значенні терміна) була альтернативною i, водночас, наближеною до фантастичного сюжету - фактичною альтернативою, запрограмованою письменником.

Так, фантастика у XX і XXI ст. стає метажанром художньої літератури, який використовує надбання своїх, колись дочірніх, жанрів, в т. ч. альтернативної історії. „Жанр, перейнятий з іншої літератури, у новому культурному середовищі зазнає певних видозмін. Взаємодія у жанрі стійкого і змінного, загальнотеоретичного й національно неповторного - одна 3 найскладніших проблем генологіі” - пише в передмові до однієї з найавторитетніших вітчизняних праць з генеалогії Н. Копистянська ${ }^{10}$. Другим чинником, що на нашу думку, нарощує кількість жанрових маркерів, що своєю чергою, збільшують розмивання меж AI, стала саме вказана дослідницею теорії жанрів проблема трансформації жанру на основі трациції конкретної національної літератури. Тому, власне, говоримо про відкриття В. Кожелянком не просто роману в жанрі AI для української літератури, а створення специфічного жанрового різновиду альтернативна історія України.

На розширення географічних меж побутування альтернативної історії (в широкому значенні терміна) ще у XIX ст. вказує у статті „Метаісторія: Історична уява в Європі XIX віку” Г. Вайт ${ }^{11}$ У У ХІХ ст. європейська циві- лізаційна теорія, а відтак й історіографія, складалась подібно до середньовічного уявлення про будову Всесвіту. Думка, що абсолютний центр розумної історії людства належить $\mathrm{CB}_{\text {- }}$ ропі, була розроблена Великобританією й підтримана надалі Францією, Італією, Німеччиною. Щоправда, поза Європою (в географічному значенні) функціонували інші теорії. Проте культурний розвиток держав нашої частини світу, зокрема літератури, дозволяв монополію на історіографію в іiі науковому та художньому вияві.

Так, пістряві й неспівмірні ідеї „варились у власному соку" протягом століть, то забуваючись, то зринаючи знову й діючи на новий лад. Ж. Ніва назвав цей процес „парниковим ефектом Європи” у статті „Народження та смерть національних міфів". Європа - це „складний ботанічний сад, в якому повинні культивуватися всі види і де уніфікація спрощеною гібридизацією відбуватися не повинна. Кожен різновид повинен мати у ньому своє місце, i за браком його він зникне, а разом 3 ним щезне ідея Свропи, тобто багатство й національне розмаїття, 3 яких зіткана Європа. Набагато простіше засадити все соснами, аніж зробити Arboretum. Європейський сад не може зрости за відсталого сільського господарства. Європа не може бути Middle-West'oм" "2. Альтернативність кожної історичної праці та роману зокрема, 3 року в рік доводила цю філософську ідею, яка розкриває внутрішню особливість Європи. 3 плином часу, реалізуючись у кожній новій національній літературі AI не тільки розширювала географічні межі, але й отримувала нові жанрові ознаки й перетворювалась 3 дочірнього жанру, утвореного на стику наукової фантастики, фентезі та історичного роману, в метажанр, що містить множину власних дочірних жарів.

Недопущення альтернатив - це історична особливість Азї (в ширшому культурологічному сенсі поняття), що вкорінилась на слов'янському просторі. Саме причина ментального колоніалізму країн колишнього СРСР й спровокувала майже цілковиту відсутність творів альтернативної історії в художніх літературах України, Білорусі, Словаччини, Болгарії до часу здобуття цими країнами політичної незалежності. Наявність великої кількості текстів AI у Росії ще не свідчить про подолання колоніального комплексу, адже важлива не тільки кількість, але й якість написаного, про що вже згадували, перефразовуючи А. Андрєєва: російські письменники не здатні створювати світи, а лише пародіюють, імітують дію. Про це влучно й безапеляційно писав також росій- 
ський письменник, московський перформер (коріння якого походить Івано-Франківська) М. Єлізаров у книзі „Мультики” 13 .

Про далеку від мобільності світоглядну концепцію та рівень майстерності митця, в східнослов'янських літературах, 3 проекцією на культурний виріб, писав ще наш видатний співвітчизник Микола Зеров: „Ох, ви, сосни мої, - азіатський край” ${ }^{\text {. }}$. Отже, глибше, „ботанічний сад" Ж. Ніви символізує штучність європейської культури, залежність ії розвитку від своїх законсервованих, повторюваних процесів, власного мікроклімату, на відміну від азіатської культури (хоча б тому, що ії простори - ширші).

Які процеси в літературі Європи відбулися в перерозкладі жанрів та їхній відголосок в Україні читаємо в працях з літературної генеалогії роману ${ }^{15}$. Що ж стосується власне українського сучасного роману, то своєрідною рисою цього різновиду в нашій літературі, яка суголосна романові в Західній Європі, є міфологізація історії в глобальному та локальному значенні цього терміна. Своєрідний порятунок від „консервування” в європейській літературі реалізує міф. В українській літературній практиці сучасного роману відбувається повторна міфілогізація, тобто створення новітнього міфу на грунті міфологеми історіографії, що побіжно зауважує в монографічній праці Т. Бовсунівська ${ }^{16}$ і що спостерігаємо в романі В. Кожелянка „Конотоп” на прикладі розшарування історичних вислідів Конотопської битви та міфологізації альтернативних варіантів історії в кожному з них.

Проте міф, народжений у Європі, якісно відрізняється від міфу Європи. Нехай назвемо тут оказіонально, так би мовити, європейський міф - внутрішнім, а міф Свропи - зовнішнім. Розкриття стратегії внутрішнього міфу та етимології й генези зовнішнього, дають у підсумку відповідь на питання про сутність Європи. Також цей аналітичний ланцюжок $є$ одним зі способів осягнення шляху від історичного роману до роману альтернативної історії, що 3'явився саме в найяскравішому прошаркові культури Свропи - в літературі. Найперше в літературі Великобританії й поширився згодом на європейські терени, до США.

Отже, розгляньмо тези М. Новикової, які дослідниця виклала у статті „Юдейсько-християнське коріння Європи"17. Почнемо 3 коментування міфів зовнішніх. Існують такі:

$\checkmark$ „Европа та давне Середземномор'я дали людству [...] єдинобожжя"18. Але, заперечує собі сама ж дослідниця, до Європи Нового часу не існувало жодної культури, яка була б атеїстичною. Не кажучи вже про те, що жодна інша культура не продукувала такого божественно-демонічного плюралізму. І вже таки напевно всі ці речі не існували одночасно й симбіотично в жодній іншій культурі. 3 цих катехізичного викладу тез бачимо, що навіть на такому початковому рівні визначення сутності Європи виникають два „світлофори” зовнішнього міфу: Свропа=свропейська культура, та вже на релігійному й філософсько-етичному планах з'являється альтернативність.

$\checkmark$ „Європа та давнє Середземномор'я дали людству[...] Боголюдськість [...] саму ідею людини як істоти, співобразної Богові"19. Але одночасно вона дала нам теорію і практику людинобожжя, яку вперше помітив Ф. Достоєвський і радо привітав Ф. Ніцше. Обидва культи зливаються в ідолопоклонстві. Альтернативи невтішні і їхня двоякість у тому, що перший - гріховний 3 погляду християнства, а другий - утопічний у формі й змісті - лишає по собі запитання: НАВІЩО?

$\checkmark$ „Европа дала людству поняття (й практику реалізації) [...] особистості"20. I майже одночасно (у співвідношенні людського життя й епох) запропонувала абсолютне знеосіблення. На поч. XXI ст. бізнесмени й політики наполягають на електронному індексуванні всього людства. Отже людина стає віртуальною, навіть у якості індивідуального існування - номером.

$\checkmark$ „Европа дала людству історію як поcmyn" 21 . Не циклічне ходіння по колу чи спіралі, а цілеспрямоване крокування до прогресу. I ця ж Європа дала людям відчуття історії як глухого кута „Про таке до- i позаєвропейські культури й (за усіх їхніх історичних драм і трагедій) гадки не мали"22. Треба зауважити, що ми (чи М. Новикова) мали на увазі не вкриту тотальним песимізмом Свропу кінця XX століття чи „Присмерк Європи" О. Шпенглера. Різкішим в обрисах та відчутнішим фаталізм історії став саме зараз, на початку другого десятиліття XXI віку. До глухого кута історії додалось ще й давнішнє відчуження. Ніде й ніколи, окрім новоєвропейського досвіду, людина не відчувала себе нічиєю. Вона належала Богові, людям, родині і роду, своїй землі. Гірке й, у певному вираженні, глобалістичне, відчуження читаємо в неймовірно емоційному та яскравому романі англійського (!) письменника П. Дібісі „Згасло світло в країні див”23.

Екстренною допомогою в реставрації такого необхідного (адже - сутнісного) міфу Європи стала альтернативна історія. Як уже зга- 
дувалося, спочатку в історіографічній практиці та галузі історичної реконструкції а згодом - у художній літературі. Спочатку - в англійській, і надалі - у всіх національних літературах Європи й США.

У літературах слов'янського світу на перешкоді альтернативній історії стояли ще два ідеологічні стовпи: приховане язичництво i тоталітаризм. Внутрішні міфи Європи („Свропа - колиска цивілізаціі”, „Англія - колиска Європи”, „Німеччина - мати філософії, „легенда про скандинавський світ”, „єдність Свропи у контрастах”, „європейське мислення”, „європейська історія (розмежовуємо 3 історією Європи)”, „Міфологічне походження Європи (у прямому сенсі - 3 давньогрецького міфу про Європу)" та ін.) в конструкції з двома вже вказаними „стовпами” творять сакралізаицію історії.

Так, у спробі подолання цієї сакралізації та на кшталт прийнятої альтернативізації кожного компонента Свропи, як ми вже зазначили, діють альтернативні history та story(s).

Отже, всі дослідження міфу Свропи можна зарахувати до суми студій 3 альтернативної історії. Міфологізм Європи завжди творив альтернативу історизму, i, водночас, вони разом - парадигму значень цієї загадкової частини світу. І дослідники про це знають.

Разом $з$ тим, письменники, що пишуть альтернативну історію не завжди роблять це абсолютно свідомо. Деякі автори вдаються до альтернативізації через технічні потреби (спосіб поєднання відчужених сюжетних ліній, складнощі із переходом між композиційними елементами) й тому не докладають зусиль оформити свої задуми жанровими й стильовими засобами AI. Тому стан розроблення жанру, як і його дослідження, подібний до айсберга: марковані тексти складають частину наявного банку творів і студій.

Альтернативи Європи і в Свропі наскрізь пов'язані 3 духом руїни. I хоч європейська культура - це сад, за визначенням Ж. Ніви, ці дві різнопланові якості успішно поєднані. Яскравим тому підтвердженням вважаємо есей Юрія Андруховича „Центрально-східна ревізія": ,[...] руїни, цей особливий слід, особливий сад колишнього буття [...] ландшафт моєї частини світу достатньо насичений цими об'єктами[...] часовий злам у провінціях відчутний загалом не так демонічно, як, наприклад, у Відні, але все ж більша частина того світу лежала в руїнах вже в мить мого народження[...]"24. Погляд українця Андруховича на т. зв. „стару Європу” - це погляд слов'янського поганина, який живе у квітучій „країні бароко” на християнську руїну Європи перманентного внутрішнього fin de siècle.

Цікаво, що момент появи поняття „,старої Європи" важко визначити, навіть складається враження, що Європа є вічно старою. А найцікавіше починається там, там на перетині цих двох світів, до яких належать Буковина та Галичина. Від Галичини до студій 3 десакралізації історії (першого кроку створення вдячного грунту для формування жанру АI) долучився Ю. Андрухович, зокрема в романі „Московіада” (1992), а від Буковини тихою і копіткою працею узявся латати літературні білі плями В. Кожелянко. Трохи альтернатив від О. Ірванця (роман „Рівне-Ровно”) та Я. Яновського (роман у співавторстві з В. Найденовою „Долина Бельведеру”), історична містифікація від Ю. Щербака (роман „Час смертохристів") - ось і весь арсенал альтернативної історії в Україні.

Рівень літературознавчого опрацювання досягнень у жанрі альтернативної історії також неоднаковий у різних країнах. США - генетична колонія Великобританії - найпершими почали творити альтернативну історію. Цей факт і не викликає подиву, адже нагальна необхідність існування власної історії реалізувалась у такий простий, 3 погляду логіки, спосіб. Багаторічний дослідник літератури в жанрі наукової фантастики та фентезі, професор кількох університетів США, письменник Дж. Клют підготував і перевидав у двохтисячних роках енциклопедію фантастики ${ }^{25}$. Видання вміщує кілька енциклопедичних статей, де згадується жанр альтернативної історії у його різнопланових ракурсах.

У полі української науки станом на 2012 рік було два дослідження, присвячених функціонуванню жанру альтернативної історії. Дослідження С. Соболєва, що вилилось у науково-публіцистичне видання „Альтернативная история: пособие для хронохичхайкеров"26 та дисертаційна праця 3 ономастики „Онімний простір постмодерністського тексту” М. Максимюк $^{27}$, що виконана на матеріалі трьох романів В. Кожелянка.

Саме ж метажанрове утворення протягом століття розшарувалось на окремі жанри та різновиди й прийняло до своїх активів численні фабульні схеми інших жанрів, зокрема канонічних, таких як історичний роман, белетристика, детективістика, хроніка, фентезі.

\section{ЛIТЕРАТУРА:}

${ }^{1}$ Sobolev S. Al'ternativnaya istoriya: posobie dlya khronokhichhajkerov [Tekst], S. Sobolev, Lipetsk 
: Krot, 2006, S.17.

2 Nicholls P., Clute J. The Encyclopedia of Science Fiction [Text] / Peter Nicholls, John Clute. - London: Orbit, 1993. - P. 714.

${ }^{3}$ Marusik I. Terorium" V. Kozhelyanka [Tekst] / I. Marusik, Ukrayina, 2005, 2 (14). - C. 14-18.

${ }^{4}$ Leksikon zagal'nogo ta porivnyal'nogo literaturoznavstva [Tekst], Za red. A. Volkova, Chernivtsi : Zoloti litavri, 2001, - S 239.

${ }^{5}$ Ibid, P. 239-240.

${ }^{6}$ Humboldt W. Von Briefwechsel an F. G. Welcker [Text] / W. von Humboldt. - 1841. - S. 49 (Nachdruck).

7 Labazov I. Al'ternativnaya istoriya $\mathrm{v}$ seti [Elektronnij resurs], Labazov Ivan, Internet LABAZ. - 03 noyabrya 2002 g. 296. - available at : http://lebed.com/2002/art3126.htm.

${ }^{8}$ Ibid.

${ }^{9}$ Laich N. O spisatelyakh-fantastah ( $\mathrm{v}$ t. ch. i Al't-Istorikah) [Elektronnyj resurs], N. Laich, XX vek Beskonechnost' vojn mirovyh : [forum]. available at : http://wap.alternatiwa.borda.ru/?1-5120-00000072-000-0-0-1106417905. - Zagl. s ekrana.

${ }^{10}$ Kopistyans'ka N. Zhanr, zhanrova sistema u prostori literaturoznavstva : [monografiya], Nonna Homivna Kopistyans'ka. - L'viv : PAIS, 2005. - S. 16.

${ }^{11}$ Hokser Al'ternativnaya istoriya [Elektronniy resurs], Vajt Gejden, Metaistoriya: Istoricheskoe voobrazhenie v Evrope XIX veka. - available at : http://militera.lib.ru (28.02.2013).

${ }^{12}$ Niva Zh. Narodzhennya ta smert' natsional'nih mifiv [Tekst], Zh. Niva, Duh i Litera, 1998, 3-4. - S. 46.

${ }^{13}$ Elizarov M. Mul'tiki [Tekst], Mihail Elizarov. M.: AST, 2010. - $317 \mathrm{~s}$.

${ }^{14}$ Zerov M. Tvori: U 2-h [Tekst], M. Zerov. - K.: Dnipro, 1990, T. 1. Istoriko-literaturni ta literaturoznavchi pratsi. - S. 588.

${ }^{15}$ Bernads'ka N. Ukrayins'kiy roman: teoretichni problemi i zhanrova evolyutsiya [ Tekst], N. Bernads'ka. - K. : Akademvidav, 2004, 368 s; Bovsunivs'ka T. Kognitivna zhanrologiya i poetika. Monografiya [Tekst], T. V. Bovsunivs'ka, K. : VPTs Kiyivs'kij universitet", 2010, 180 s; Buzina O. Porazka na polyakh paralel'noyi istoriyi [Tekst], O. Buzina, Kiyivs'ki vidomosti, 2000, 29 veres. - S. 22; Yatsuk O. Ekspresivnist' yak vidchuttya diysnosti u romanakh Vasilya Kozhelyanka Defilyada v Moskvi", Lzhenostradamus" [Tekst], O. Yatsuk, Mandrivets', 2003. - 3. - S. 47 51.
16 Bovsunivs'ka T. Kognitivna zhanrologiya i poetika. Monografiya [Tekst], T. V. Bovsunivs'ka, K. : VPTs Kiyivs'kiy universitet", 2010, $180 \mathrm{~s}$

17 Novikova M. Mifi ta misiya [Tekst], M. Novikov, K. : Duh i Litera, 2005, 432 s.

${ }^{18}$ Ibid, P. 346.

${ }^{19}$ Ibid, P. 346.

${ }^{20}$ Ibid, P. 346.

${ }^{21}$ Ibid, P. 347.

${ }^{22}$ Ibid, P. 347.

${ }^{23}$ Dibisi P. Svitlo zgaslo v Krayini Div. Roman [Tekst], perekl. z angl. G. Shiyan, L'viv : Liga Pres, 2012. - $360 \mathrm{~s}$.

${ }^{24}$ Moya Yevropa. Dva eseyi pro najdivnishu chastinu svitu Andzheya Stasyuka i Yuriya Andruhovicha [Tekst], A. Stasyuk, Yu. Andruhovich, L'viv : VNTL-Klasika, 2007, C.111-112.

${ }_{25}$ Nicholls P., Clute J. The Encyclopedia of Science Fiction [Text] / Peter Nicholls, John Clute. - London: Orbit, 1993. - 1408 p.

${ }^{26}$ Sobolev S. Al'ternativnaya istoriya: posobie dlya hronohichhajkerov [Tekst], S. Sobolev, Lipetsk : Krot, 2006. - 232 s.

${ }^{27}$ Maksimyuk M. Onimniy prostir postmodernists'kogo tekstu (na materiali tvoriv Vasilya Kozhelyanka) [Tekst], dis. na zdobuttya nauk. st. kandidata nauk M. Maksimyuk. - Chernivtsi : Ruta, 2012, - 268 s.

\section{Anistratenko Antonina. CURRENT STA- TUS, DEVELOPMENT AND RESERCH OF ALTERNATIVE HISTORY AS METAGEN- RE}

Structure of modern text demonstrates a new understanding of the traditional principle of reflection. Thanks to this mimetic attraction the story gets to a new syncretism level "text-idea." It lies in the recovering the series of moments of life which have been seen or imagined by the author and displayed using artistic means and genre models. With the special way it change the genre its modern condition and realized itself in the new form. This article deals with alternative history genre genesis and Ukrainian alternative novels in world literary context, its particular, aesthetic, thematic, genre features of science fiction, connection with the typical Ukrainian novel.

Special characters of Alternative history genre are combined in modern postmodern novel and use it like form for new sense. This refers to the approach of literature to document, to the real fact and the creation of the impression of extracredibility through direct imitation of linguistic and cultural code of journalism. 
Criticism of society is the most significant motif of creativity in $\mathrm{AH}$ various formal and semantic schemes of the fiction novels. For ex. in the frame of an ironic writer gives a long-term scheme of the internal economic and legal slavery of the citizens of their country. Social and sociopsychological topics are among of interest to authors of fiction genres and alternative history of the last century.

Key words: alternative history, genre features, genesis of genre, science fiction, historical novel, reflection, novel.

Received 29-10-2015

Advance Acces Publischer: November 2015 